Patrycja Chodnicka-Jaworska

\title{
OCZEKIWANIE ZMIANY NASTAWIENIA CREDIT RATINGS BANKÓW A KURSY AKCJI PRZY UWZGLĘDNIENIU POZIOMU ROZWOJU GOSPODARCZEGO KRAJU
}

\section{Wprowadzenie}

Celem agencji ratingowych jest ocena emitenta lub wypuszczanego przez niego papieru wartościowego pod względem ryzyka upadłości. W związku z tym publikują wyniki swojej oceny, tj. credit ratings. Oprócz tego do opinii publicznej podawane są informacje na temat przyszłych oczekiwanych zmian, czyli outlooks i credit watch. Credit watch określa kierunek zmiany krótkoterminowej. Ma charakter pozytywny, negatywny, stabilny bądź nieokreślony (developed). O nastawieniu i długoterminowej zmianie, najczęściej w okresie od sześciu miesięcy do dwóch lat, decyduje outlook. Ma charakter analogiczny do credit watch. Informacje publikowane przez agencje ratingowe wywierają silny wpływ na funkcjonowanie rynku finansowego. Zmiana credit ratings w sposób istotny statystycznie oddziałuje na kursy akcji, obligacji, kursy walutowe, stopy procentowe czy spready na CDS-ach. Jednocześnie powstaje pytanie o reakcje rynku na same zmiany nastawienia not ratingowych.

W związku z tym celem artykułu stała się weryfikacja wpływu zmian oczekiwań credit ratings banków na stopy zwrotu $\mathrm{z}$ akcji banków, przy uwzględnieniu poziomu rozwoju gospodarczego. Postanowiłam zweryfikować wpływ zmian nastawienia na ceny akcji instytucji z sektora bankowego ze względu na jego specyfikę funkcjonowania oraz zaostrzony nadzór. Postawiłam hipotezę badawczą: Ceny akcji banków reagują silniej na obniżkę oczekiwań credit ratings banków zarówno w przypadku krajów rozwiniętych, jak i rozwijających się. Do weryfikacji hipotezy badawczej wykorzystałam metodę event study. Badanie zostało przeprowadzone na danych dziennych dla lat 1990-2015.

\footnotetext{
1 Dr Patrycja Chodnicka-Jaworska, Katedra Systemów Finansowych Gospodarki, Wydział Zarządzania, Uniwersytet Warszawski.
} 
Artykuł składa się z pięciu części. Rozpoczyna się wprowadzeniem, następnie dokonałam przeglądu literatury. W punkcie trzecim została przedstawiona zastosowana metodologia badawcza oraz charakterystyka danych. Kolejna część to opis wyników badań zwieńczony zakończeniem.

\section{Przegląd literatury}

Przeprowadzono szereg badań na temat wpływu credit ratings na zachowania kursów instrumentów finansowych. Dotychczas zweryfikowano oddziaływanie zmian not ratingowych na kursy obligacji, stóp procentowych, spreadów na CDS-ach czy kursów walut. Badaniom poddawano również oddziaływanie na kursy akcji. $\mathrm{W}$ przeprowadzanych analizach brano pod uwagę różny horyzont czasowy i próbę badawczą. Najczęściej badania prowadzono na danych dotyczących spółek z sektora przemysłowego. Mieszano również próby badawcze. Jednym z pierwszych, a zarazem najpopularniejszych badań była analiza przeprowadzona przez Griffin i Sanvicente². Opierała się ona na weryfikacji wpływu zmiany credit rating przedsiębiorstwa na jego kursy akcji. Nie odkryto zależności pomiędzy analizowanymi zmiennymi, zwrócono jednak uwagę na wpływ obniżki ratingu na kursy akcji po dokonaniu podziału zgodnie z kierunkiem zmiany noty. Wadą przeprowadzonego badania było uwzględnienie danych miesięcznych, a nie dziennych, co z pewnością wpłynęło na wyniki. Analizę na danych dziennych po raz pierwszy przeprowadzili Holthausen i Leftwich'3 weryfikując wpływ 1014 zmian not Moody i S\&P oraz 256 nastawień. Nie zauważyli oni istotnego statystycznie wpływu wzrostu ratingu, podkreślili jednak negatywne oddziaływanie pogorszenia oceny i nastawienia. Podobne wnioski otrzymali Hand, Holthausen i Leftwich ${ }^{4}$, prowadząc badania dla rynków obligacji i akcji oraz Calderoniet al. ${ }^{5}$, analizując zachowanie kursów akcji banków w latach 2002-2007 w efekcie zmiany noty przez Moody.

2 P.A. Griffin, A.Z. Sanvicente, Common Stock Returns and Rating Changes: A Methodological Comparison, „Journal of Finance” 1982, No. 37, s. 103-120.

3 R.W. Holthausen, R.W. Leftwich, The Effect of Bond Rating Changes on common Stock Prices, „Journal of Financial Economics" 1986, No. 17, s. 57-89.

4 J.R.M. Hand, R.W. Holthausen, R.W. Leftwich, The Effect of Bond Rating Agency Announcements on Bond and Stock Prices, „The Journal of Finance” 1992, Vol. 47, No. 2, s. 733-752.

5 F. Calderoni, P. Colla, S. Gatti, Rating Changes: The European Evidence, „Carefin Research Paper Series” June 2009. 
Pierwsze badania dotyczące wpływu zmian credit ratings na kursy akcji banków przeprowadzili Schweitzer et al. ${ }^{6}$ Podkreślili oni różnice pomiędzy zachowaniem cen akcji banków i akcji firm z sektora przemysłowego. Jest to efekt zaostrzonego nadzoru bankowego, który skutecznie reaguje na zmiany kondycji sektora. Podkreślono ponadto, iż w momencie ogłoszenia ratingu związek pomiędzy tymi dwoma zmiennymi ma słaby charakter. Zauważono, że stopy zwrotu w związku z obniżką not spadają o 1,5\%, a w okresie przed ogłoszeniem o 10-20\%. Stwierdzono również istotność poprawy noty ratingowej, która powoduje ponadnormalne stopy zwrotu w wysokości $1 \%$. Kolejne badania zostały zaproponowane przez Gropp i Richards ${ }^{7}$. Przeanalizowali oni wpływ zmian credit ratings banków nadawanych przez trzy największe agencje ratingowe, a mianowicie przez S\&P, Fitch, Moody. Stwierdzili, iż poprawa credit rating powoduje wzrost ponadnormalnej stopy zwrotu o 1,2\% w momencie ogłoszenia i o $1,5 \% \mathrm{w}$ ciągu trzech dni po ogłoszeniu zmiany noty.

Badania na temat wpływu credit ratings na kursy akcji najczęściej opierały się na analizie rynków lokalnych i tak Bremer oraz Pettway ${ }^{8}$ zweryfikowali zachowanie akcji banków japońskich. Nie zauważyli istotnego statystycznie związku pomiędzy zamianą ratingu a stopami zwrotu w okresie publikacji ani po jej ogłoszeniu przy uwzględnieniu średniej z ostatniego roku. Poszerzając zakres danych do wyznaczenia średniej do dwóch lat, stwierdzili istotny wpływ spadku noty ratingowej na kurs akcji i obniżkę stopy zwrotu o blisko 20,6\%.

Badania prowadzono również w podgrupach. Na przykład Jones i Mulet-Marquis ${ }^{9}$ porównali banki amerykańskie z zagranicznymi. Zauważyli, że akcje banków amerykańskich są bardziej wrażliwe na obniżki not. Z kolei Hiu, Nuttawat i Puspakaran ${ }^{10}$ zestawili zachowanie akcji w efekcie zmian krótko- i długoterminowych ratingów banków. Stwierdzili, że rynek nie jest wrażliwy na publikację informacji na temat krótkoterminowych zmian. Ponadto podkreślili, że na małym i płynnym rynku zmiany not ratingowych dostarczają małej ilości informacji dla inwestorów przy

6 R. Schweitzer, S. Szewczyk, R. Varma, Bond Rating Agencies and Their Role in Bank Market Discipline, „Journal of Financial Services Research” 1992, No. 6, s. 249-263.

7 R. Gropp, A.J. Richards, Rating agency actions and the pricing of debt and equity of European banks: what can we infer about private sector monitoring of bank soundness?, „ECB Working Paper” August 2001, No. 76.

8 M. Bremer, R.H. Pettway, Information and the market's perceptions of Japanese bank risk: Regulation, environment, and disclosure, „Pacific-Basin Finance Journal” 2002, No. 10, s. 119-139.

9 E. Jones, Q. Mulet-Marquis, The Stock Market Reaction to Changes to Credit Ratings of US-Listed Banks, "Centre for Finance and Investment Discussion Paper Series” September 2014, DP2013-AEF03, British Accounting and Finance Association(BAFA) Scottish Area Group Conference.

10 L. Hiu, V. Nuttawat, K. Puspakaran, Effects of credit rating announcements: the Swedish stock market, „International Journal of Finance” 2004, Vol. 16, No. 1, s. 28-72. 
podejmowaniu decyzji. Almeida et al. ${ }^{11}$ postanowili przeprowadzić badanie w dwóch podgrupach, a mianowicie na instytucjach finansowych z 80 krajów, które mają oraz nie mają nadanego ratingu. Analizy dokonali na notach publikowanych przez trzy największe agencje ratingowe w latach 1990-2012. Zauważyli, iż obniżka ratingu powoduje silniejszy spadek inwestycji w podmioty, które go posiadają. Podział dotyczący zachowania rynku akcji na zmiany samych credit ratings, który zaproponowali Vassalou i Xing ${ }^{12}$, postanowiono wykorzystać do badania oddziaływania zmian outlooks i credit watch zaprezentowanych w niniejszym artykule. Stwierdzili oni, iż wielkość rynku kapitałowego, poziom rozwoju gospodarczego, prawdopodobieństwo upadłości odgrywają istotną rolę przy analizie wpływu zmian ratingów na kursy akcji. Istotnym momentem jest czas przed i po publikacji informacji. Badania nad wpływem kryzysu finansowego dokonał Grothe ${ }^{13}$.

Istnieje natomiast luka badawcza w zakresie analizy wpływu zmian outlooks lub credit watch na kursy akcji. Większość badań odnosi się do rynku lokalnego: banków z Nowej Zelandii (Elayan, Hsu i Meyer ${ }^{14}$ ), Szwecji (Li, Visaltanachoti, Kesayan ${ }^{15}$ ), Indii $\left(R a o, \mathrm{U}^{16}\right)$. Weryfikowano również wpływ zmian nastawienia poszczególnych agencji ratingowych: S\&P (Agarwal, Chen, Zhang ${ }^{17}$ ), Moody (Beckmann, Jin ${ }^{18}$ ), nie dotyczyły one jednak sektora bankowego. Badania dla krajów rozwijających się przeprowadził Mateev ${ }^{19}$. Przeanalizował on jednak rynek instytucji spoza sektora finansowego. W swoich analizach podjął kwestię międzynarodowego efektu zakażenia. Zwrócił uwagę, że w krajach rozwijających się najsilniejszy wpływ zmiana ratingu wywiera na poziomie lokalnym, lecz można również zauważyć istotne statystycznie różnice w stopach zwrotu w krajach sąsiadujących.

11 H. Almeida, I. Cunha, M.A. Ferreira, F. Restrepo, The Real Effects of Credit Ratings: The Sovereign Ceiling Channel, „Journal of Finance” 2016, w druku.

12 M. Vassalou, Y. Xing, Equity returns following changes in default risk: New insights into the informational content of credit ratings, „Working Paper Columbia University” 2003.

13 M. Grothe, Market pricing of credit rating signals, „EBC Working Paper Series” December 2013, No. 1623.

14 F.A. Elayan, W.H. Hsu, T.O. Meyer, The informational content of credit rating announcements for share prices in a small market, „Journal of Economics and Finance” 2003, Vol. 27, No. 3, s. 337-356.

$15 \mathrm{H}$. Li, N. Visaltanachoti, P. Kesayan, The Effects of Credit Rating Announcements on Shares in the Swedish Stock Market, „International Journal of Finance” 2004, Vol. 16, Issue 1, s. 28-72.

16 S.V.D. N. Rao, S. U, Impact of Credit Ratings (Upgrade and Downgrade) on Stock Prices in India, Proceedings of $23^{\text {rd }}$ International Business Research Conference, 18-20 November 2013, Marriott Hotel, Melbourne, Australia, ISBN: 978-1-922069-36-81.

17 S. Agarwal, V. Chen, W. Zhang, The Information Value of Credit Rating Reports, „Management Science” 2016, Vol. 62, Issue 7.

18 K.S. Beckmann, C. Jin, The Impact of REIT Ratings on Stock Price and Shareholder Wealth, „International Real Estate Review" 2013, Vol. 16, No. 2, s. 134-146.

19 M. Mateev, The Effect of Sovereign Credit Rating Announcements on Emerging Bond and Stock Markets: New Evidences, „Oxford Journal: An International Journal of Business \& Economics” 2012, No. 7(1), s. $28-41$. 
Pierwsze badania na temat wpływu zmian nastawienia przeprowadzili Richards i Deddouche ${ }^{20}$. Stwierdzili oni, iż istotniejsze z punktu widzenia ponadnormalnych stóp zwrotu są informacje publikowane na temat zmiany nastawienia niż zmiany samego credit rating. Linciano ${ }^{21}$ przeanalizowała wpływ 299 zmian oczekiwań wobec credit ratings publikowanych przez Wielką Trójkę włoskim firmom. Okazało się, że istotny wpływ ma tylko spadek noty i nastawienia, zauważono jednak również, że spadek stóp zwrotu jest niższy w przypadku instytucji finansowych. Istotność wpływu sektora oraz wielkości firmy na analizowaną zmienną podkreślili również Poon i Chan ${ }^{22}$. Badania przeprowadzone przez Klimavičienè $\dot{2}^{23}$ na próbie banków nadbaltyckich wskazało na występowanie różnic we wpływie zmian oczekiwań publikowanych przez poszczególne agencje na kursy akcji. Podkreślono również istotność statystyczną wpływu zarówno podwyżki, jak i obniżki not ratingowych. Wskazano jednak na występowanie silniejszego wpływu obniżki niż podwyżki oczekiwań.

Przeprowadzone badania literaturowe skłoniły mnie do analizy wpływu zmian oczekiwań wobec credit ratings publikowanych przez trzy największe agencje ratingowe na stopy zwrotu z cen akcji banków europejskich. Podjęcie kwestii analizy sektora bankowego jest wynikiem innego zachowania się rynku finansowego w wyniku publikacji informacji na temat credit ratings. Dotychczasowe badania nie dają jednoznacznych wyników co do wpływu kierunku nastawienia. Nie był dotychczas analizowany wpływ poziomu rozwoju gospodarczego na oddziaływanie oczekiwań dotyczących zmiany credit rating na ponadnormalne stopy zwrotu z cen akcji banków. W związku z tym celem artykułu stała się weryfikacja wpływu zmian oczekiwań credit ratings banków na stopy zwrotu $\mathrm{z}$ akcji banków, przy uwzględnieniu poziomu rozwoju gospodarczego. Postawiłam hipotezę badawczą: Ceny akcji banków reagują silniej na obniżkę oczekiwań credit ratings banków zarówno w przypadku krajów rozwiniętych, jak i rozwijających się. W dalszej części artykułu została opisana metodologia oraz otrzymane wyniki badań.

\footnotetext{
20 A. Richards, D. Deddouche, Bank rating changes and bank stock returns - puzzling evidence from the emerging markets, „IMF Working Papers” 1999, No. WP/99/151.

21 N. Linciano, The reaction of stock prices to rating changes, „CONSOB Quaderni di Finanza” June 2004, No. 57.

22 W.P.H. Poon, K.C. Chan, An Empirical Examination of the Informational Content of Credit Ratings in China, „Journal of Business Research” 2007, Vol. 61, No. 7, s. 790-797.

23 A. Klimavičiene, Sovereign Credit Rating Announcements and Baltic Stock Markets, „Organizations and Markets in Emerging Economies" 2011, Vol. 2, No. 1(3), s. 51-62.
} 


\section{Metodologia badawcza i opis danych}

Dotychczasowe badania zróżnicowane są pod względem wykorzystanej próby badawczej, okna zdarzenia czy interwału czasowego. Analizy przeprowadzono również dla innych agencji ratingowych. Do badania postanowiłam wykorzystać dane dzienne ze względu na wysoką zmienność rynku akcji ${ }^{24}$. Do weryfikacji postawionej hipotezy wykorzystałam metodę event study. Badanie przeprowadziłam na różnicach zlogarytmowanych dziennych stóp zwrotu $\mathrm{z}$ akcji banków europejskich. Jako zdarzenie potraktowałam publikację informacji o zmianie nastawienia, czyli outlooks i credit watch wobec credit ratings banków publikowanych przez wszystkie agencje ratingowe w latach 1980-2015. Dane do badania zostały pozyskane z bazy Thomson Reuters.

Celem metody event study jest określenie ponadnormalnych skumulowanych różnic (CAD), przy założeniu, że brak jest innych czynników, które miały miejsce w tym czasie. Ze względu na wysoką zmienność cen akcji zastosowałam okno zdarzenia składające się z 10 dni przed rzeczywistym terminem zdarzenia (2 tygodnie robocze) i 10 dni po konkretnym wydarzeniu. Tak więc w sumie 21 dni sesyjnych, określonych w przedziale czasu jako $[-11,+12]$. Okres $[-1,+2]$ to okno zdarzenia, natomiast $[-11,-2]$ i $[+3,+12]$ to okno zmian przed wydarzeniem i odpowiednio po wydarzeniu. Dzień publikacji informacji oznaczany jest jako 0. Do weryfikacji poprawności modeli stosowane są testy statystyczne oparte na podnormalnych różnicach, które oznacza się jako różnicę między rzeczywistą wartością spreadu na każdy dzień w oknach zdarzeń i wartością oczekiwaną mierzoną jako średnia dziennych różnic dla poprzednich $60 \mathrm{dni}$ roboczych poprzedzających okna zdarzenia. $\mathrm{W}$ ten sposób otrzymujemy ponadnormalne różnice, których statystyczną odróżnialność od zera sprawdzamy za pomocą statystyki t-Studenta w odpowiednich podgrupach. Testy parametryczne przypisują równe szanse na osiągnięcie zarówno pozytywnych, jak i negatywnych odchyleń od wartości oczekiwanej. Mała liczba obserwacji może osłabić moc testów statystycznych, co sugeruje, że należy rozważyć zarówno znaczenie ekonomiczne, jak i statystyczne wyników.

Badanie zostało przeprowadzone w podgrupach. Pierwszy podział wynika z poprawy lub pogorszenia nastawienia wobec credit rating banku. Według drugiego podziału dokonałam klasyfikacji banków - zgodnie z kategoryzacją proponowaną przez Bank Światowy - względem poziomu rozwoju gospodarczego kraju, w którym dany bank funkcjonuje.

24 M. Steiner, V.G. Heinke, Event Study Concerning International Bond Price Effects on Credit Rating Actions, „International Journal of Finance and Economics” 2001, No. 6, s. 139-157. 
Tabela 1. Lista krajów według poziomu rozwoju gospodarczego zgodnie z podziałem zaproponowanym przez Bank Światowy

\begin{tabular}{|l|l|}
\hline \multicolumn{1}{|c|}{ Podział ekonomiczny } & \multicolumn{1}{c|}{ Kraj } \\
\hline $\begin{array}{l}\text { Wysoko rozwinięte kraje będące } \\
\text { członkami OECD }\end{array}$ & $\begin{array}{l}\text { Austria, Belgia, Czechy, Dania, Estonia, Finlandia, Francja, Grecja, Hiszpania, } \\
\text { Holandia, Irlandia, Islandia, Luksemburg, Niemcy, Norwegia, Polska, Portugalia, } \\
\text { Słowacja, Słowenia, Szwajcaria, Szwecja, Węgry, Wielka Brytania, Włochy }\end{array}$ \\
\hline $\begin{array}{l}\text { Wysoko rozwinięte kraje niebędące } \\
\text { członkami OECD }\end{array}$ & Chorwacja, Cypr, Liechtenstein, Malta \\
\hline $\begin{array}{l}\text { Gospodarki o ponadprzeciętnym } \\
\text { dochodzie }\end{array}$ & $\begin{array}{l}\text { Białoruś, Bośnia i Hercegowina, Bułgaria, Czarnogóra, Litwa, Łotwa, Macedonia, } \\
\text { Rosja, Rumunia, Serbia, Turcja }\end{array}$ \\
\hline $\begin{array}{l}\text { Gospodarki o dochodzie } \\
\text { poniżejprzeciętnym }\end{array}$ & Albania, Armenia, Gruzja, Mołdawia, Ukraina \\
\hline
\end{tabular}

Źródło: Opracowanie własne.

\section{Opis wyników badania}

Badanie wpływu zmian outlooks i watch list na stopy zwrotu z akcji banków europejskich rozpoczęłam od analizy wpływu samego kierunku zmian. Wyniki badań zostały przedstawione $\mathrm{w}$ tabeli 2 . W przypadku outlooks nie obserwuje się istotnego statystycznie wpływu poprawy not ratingowych, natomiast rynek akcji ulega korektom w wyniku obniżki. Stopy zwrotu spadają w okresie post-event window o blisko 0,74 pkt. proc. W sytuacji ogłoszenia informacji o zmianach watch list istotny statystycznie wpływ obserwuje się zarówno w przypadku poprawy, jak i pogorszenia nastawienia krótkoterminowego. Stopy zwrotu z rynku akcji spadają o blisko 5,9 pkt. proc. w wyniku spadku nastawienia, rosną o blisko 4,5 pkt. proc. w czasie ogłoszenia informacji o podwyżce oraz o blisko 4,54 pkt. proc. w okresie po jej ogłoszeniu. Rynek akcji silniej reaguje na informacje na temat pogorszenia nastawienia krótko- i długoterminowego niż jego poprawy, co jest zgodne z dotychczasowymi badaniami.

Tabela 2. Wpływ zmian outlooks i watch list na stopy zwrotu $\mathrm{z}$ akcji banków europejskich

\begin{tabular}{|l|c|c|c|c|}
\hline \multirow{2}{*}{ Zmiana } & \multicolumn{2}{|c|}{ Outlook } & \multicolumn{2}{c|}{ Watch list } \\
\cline { 2 - 5 } & $\mathrm{U}$ & $\mathrm{D}$ & $\mathrm{U}$ & $\mathrm{D}$ \\
\hline \multicolumn{4}{|c|}{ pre-event window } \\
\hline Cons & $-0,003$ & 0,00062 & 0,0184 & 0,0092 \\
\hline & $(-0,83)$ & $-0,06$ & $(-0,65)$ & $-0,26$ \\
\hline$N$ & 475 & 542 & 13 & 16 \\
\hline
\end{tabular}




\begin{tabular}{|l|c|c|c|c|}
\hline \multirow{2}{*}{ Zmiana } & \multicolumn{2}{|c|}{ Outlook } & \multicolumn{2}{c|}{ Watch list } \\
\cline { 2 - 5 } & $\mathrm{U}$ & $\mathrm{D}$ & $\mathrm{U}$ & $\mathrm{D}$ \\
\hline \multicolumn{5}{|c|}{ event window } \\
\hline \multirow{2}{*}{ cons } & $-0,0028$ & 0,00298 & $0,0453^{* * *}$ & $-0,0015$ \\
\hline \multirow{5}{*}{$N$} & $(-1,46)$ & $-1,16$ & $(-4,85)$ & $(-0,05)$ \\
\hline & 475 & 542 & 13 & 16 \\
\hline cons & $-0,0013$ & $-0,0074^{*}$ & $0,0454^{*}$ & $-0,0586^{*}$ \\
\hline \multicolumn{5}{|c|}{ post-event window } \\
\hline$N$ & $(-0,46)$ & $(-1,88)$ & $(-1,95)$ & $(-2,27)$ \\
\hline
\end{tabular}

Źródło: Opracowanie własne.

Następnie badanie zostało przeprowadzone w podziale na poszczególne agencje ratingowe. Wyniki analizy zaprezentowałam w tabelach 3 i 4.

Spośród analizowanych zmian outlooks tylko Fitch long term default oraz R\&I long term issuer outlook wywierają istotny statystycznie wpływ na zmiany stóp zwrotu $\mathrm{z}$ akcji banków europejskich. W wyniku poprawy nastawienia długoterminowego nadawanego przez Fitch stopy zwrotu rosną w okresie przed zmianą o 1,8 pkt. proc., a po zmianie o 1,6 pkt. proc. Natomiast w przypadku R\&I rynek reaguje w okresie pre-event window i stopy ulegają pozytywnej korekcie o 2,3 pkt. proc. W przypadku ogłoszenia negatywnych zmian outlooks rynek akcji silniej reaguje na zmiany. Ponadto więcej korekt różnych agencji wpływa w sposób istotny na ponadnormalne stopy zwrotu. Zróżnicowany jest również sam moment reakcji. Okazuje się bowiem, że ceny akcji reagują w momencie ogłoszenia informacji w przypadku nastawień publikowanych przy Fitch long term issuer outlook oraz Moody's long term bank depo sit outlook (odpowiednio spadek stóp o 3,95 pkt. proc. oraz 1,04 pkt. proc.). Pogorszenie JCR long term issuer outlook skutkuje negatywną korektą na stopach zwrotu przed i w trakcie ogłoszenia odpowiednio o 3,9 oraz 2,5 pkt. proc. Natomiast w przypadku Moody's senior unsecured outlook spadek stóp ma miejsce w oknie zdarzenia i po nim odpowiednio o 1,9 pkt. proc. oraz 2,6. Inaczej wygląda sytuacja w przypadku S\&P long term issuer outlook, bowiem istotny statystycznie spadek stóp zwrotu na cenach akcji banków europejskich następuje przed i po ogłoszeniu informacji o 2,1 pkt. proc. oraz 1,1 pkt. proc. 
Tabela 3. Wpływ poprawy outlook na stopy zwrotu $\mathrm{z}$ akcji banków europejskich $\mathrm{w}$ podziale na poszczególne credit ratings

\begin{tabular}{|c|c|c|c|c|c|c|c|c|c|c|c|c|c|c|}
\hline $\begin{array}{l}\text { Credit } \\
\text { rating }\end{array}$ & $\begin{array}{c}\text { Fitch } \\
\text { long } \\
\text { term } \\
\text { default }\end{array}$ & $\begin{array}{c}\text { Fitch } \\
\text { Long- } \\
\text { term } \\
\text { National }\end{array}$ & $\begin{array}{l}\text { Fitch } \\
\text { long } \\
\text { term } \\
\text { issuer }\end{array}$ & $\begin{array}{l}\text { JCR long } \\
\text { term } \\
\text { issuer }\end{array}$ & $\begin{array}{l}\text { Moody's } \\
\text { Backed Senior } \\
\text { Unsecured }\end{array}$ & $\begin{array}{l}\text { Moody's } \\
\text { Long-term } \\
\text { Issuer }\end{array}$ & $\begin{array}{l}\text { Moody's } \\
\text { Senior } \\
\text { Unsecured }\end{array}$ & $\begin{array}{c}\text { R\&l } \\
\text { Long- } \\
\text { term } \\
\text { Issuer }\end{array}$ & $\begin{array}{c}\text { S\&P } \\
\text { Long- } \\
\text { term } \\
\text { Issuer }\end{array}$ & $\begin{array}{l}\text { Moody's } \\
\text { Bank } \\
\text { Financial } \\
\text { Strength }\end{array}$ & $\begin{array}{c}\text { Moody's } \\
\text { Junior } \\
\text { Subordinated }\end{array}$ & $\begin{array}{c}\text { Moody's } \\
\text { Long- } \\
\text { term } \\
\text { Bank } \\
\text { Deposit }\end{array}$ & $\begin{array}{l}\text { Moody's } \\
\text { Subordinated }\end{array}$ & $\begin{array}{c}\text { S\&P } \\
\text { Senior } \\
\text { Secured }\end{array}$ \\
\hline \multicolumn{15}{|c|}{ pre-event window } \\
\hline \multirow[t]{2}{*}{ cons } & $0,0182^{*}$ & 0,0141 & 0,0211 & 0,00197 & $-0,0493$ & $-0,0046$ & 0,0302 & $0,0223^{*}$ & $-0,0027$ & 0,0433 & $0,0611^{*}$ & 0,0123 & $-0,0229$ & $-0,0552^{\prime}$ \\
\hline & $(-2,51)$ & $-0,79$ & $-1,27$ & $-0,07$ & $(-0,99)$ & $(-0,39)$ & $-0,83$ & $(-1,77)$ & $(-0,57)$ & $-1,17$ & $(-1,73)$ & $-0,74$ & $(-1,17)$ & $(-1,79)$ \\
\hline N & 102 & 19 & 31 & 10 & 2 & 6 & 12 & 33 & 197 & 9 & 2 & 43 & 6 & 2 \\
\hline \multicolumn{15}{|c|}{ event window } \\
\hline \multirow[t]{2}{*}{ _cons } & 0,0044 & 0,00116 & $-0,0107$ & 0,00033 & $-0,0271$ & $-0,0104$ & $-0,0104$ & 0,0087 & $-0,0041$ & $0,0185^{\star}$ & 0,0188 & 0,00863 & $0,0292^{*}$ & 0,0108 \\
\hline & $(-0,93)$ & $-0,12$ & $(-1,27)$ & $-0,03$ & $(-1,29)$ & $(-1,13)$ & $(-1,36)$ & $(-1,28)$ & $(-1,46)$ & $-1,78$ & $-0,51$ & $-1,23$ & $-1,79$ & $-1,23$ \\
\hline N & 102 & 19 & 31 & 10 & 2 & 6 & 12 & 33 & 197 & 9 & 2 & 43 & 6 & 2 \\
\hline \multicolumn{15}{|c|}{ post-event window } \\
\hline \multirow[t]{2}{*}{ cons } & $0,0166^{\star \star}$ & $-0,0104$ & $-0,0033$ & $-0,0259$ & $-0,0011$ & $-0,0063$ & 0,0112 & 0,0123 & 0,00745 & 0,0156 & $0,024^{\star \star \star}$ & 0,00535 & 0,0125 & 0,0342 \\
\hline & $(-2,68)$ & $(-0,78)$ & $(-0,26)$ & $(-1,57)$ & $(-0,03)$ & $(-0,59)$ & $-0,79$ & $(-1,15)$ & $-1,62$ & $-0,58$ & $(-8,49)$ & $-0,59$ & $-1,2$ & $-0,72$ \\
\hline$N$ & 102 & 19 & 31 & 10 & 2 & 6 & 12 & 33 & 197 & 9 & 2 & 43 & 6 & 2 \\
\hline
\end{tabular}

Źródło: Opracowanie własne. 
Tabela 4. Wpływ pogorszenia outlook na stopy zwrotu z akcji banków europejskich w podziale na poszczególne credit ratings

\begin{tabular}{|c|c|c|c|c|c|c|c|c|c|c|c|}
\hline $\begin{array}{l}\text { Credit } \\
\text { rating }\end{array}$ & $\begin{array}{l}\text { Fitch long } \\
\text { term default }\end{array}$ & $\begin{array}{l}\text { Fitch Long- } \\
\text { term National }\end{array}$ & $\begin{array}{l}\text { Fitch long } \\
\text { term issuer }\end{array}$ & $\begin{array}{l}\text { JCR long } \\
\text { term issuer }\end{array}$ & $\begin{array}{l}\text { Moody's } \\
\text { Long-term } \\
\text { Issuer }\end{array}$ & $\begin{array}{l}\text { Moody's } \\
\text { Senior } \\
\text { Unsecured }\end{array}$ & $\begin{array}{l}\text { R\&I Long- } \\
\text { term Issuer }\end{array}$ & $\begin{array}{l}\text { S\&P Long- } \\
\text { term Issuer }\end{array}$ & $\begin{array}{c}\text { Moody's } \\
\text { Bank } \\
\text { Financial } \\
\text { Strength }\end{array}$ & $\begin{array}{c}\text { Moody's } \\
\text { Long-term } \\
\text { Bank Deposit }\end{array}$ & $\begin{array}{l}\text { Moody's } \\
\text { Subordinated }\end{array}$ \\
\hline \multicolumn{12}{|c|}{ pre-event window } \\
\hline \multirow[t]{2}{*}{ _cons } & 0,0373 & $-0,003$ & $-0,0236$ & $-0,0391^{*}$ & 0,00416 & $-0,0059$ & 0,00589 & $-0,0210^{* * *}$ & 0,0477 & $-0,0047$ & $-0,0114$ \\
\hline & $-0,88$ & $(-0,19)$ & $(-1,26)$ & $-2,35$ & $-0,24$ & $(-0,49)$ & $-0,53$ & $(-3,96)$ & $-1,85$ & $(-0,61)$ & $(-0,65)$ \\
\hline$N$ & 132 & 22 & 23 & 10 & 10 & 21 & 41 & 217 & 10 & 46 & 8 \\
\hline \multicolumn{12}{|c|}{ event window } \\
\hline \multirow[t]{2}{*}{ _cons } & 0,0102 & 0,014 & $-0,0395^{\star}$ & $-0,0247^{*}$ & $3,9 \mathrm{E}-05$ & $-0,0191^{* *}$ & $-0,013$ & 0,00323 & 0,00529 & $-0,0104^{\star}$ & $-0,0151$ \\
\hline & $-1,85$ & -1 & $-2,26$ & $(-2,33)$ & 0 & $(-3,16)$ & $(-1,05)$ & $-0,81$ & $-0,43$ & $(-2,25)$ & $(-0,93)$ \\
\hline$N$ & 132 & 22 & 23 & 10 & 10 & 21 & 41 & 217 & 10 & 46 & 8 \\
\hline \multicolumn{12}{|c|}{ post-event window } \\
\hline \multirow[t]{2}{*}{ _cons } & $-0,0094$ & 0,0242 & $-0,0022$ & $-0,0216$ & $-0,0012$ & $-0,0264^{*}$ & 0,0124 & $-0,0115^{\star}$ & 0,0188 & $-0,011$ & $-0,0103$ \\
\hline & $(-0,83)$ & $-1,14$ & $(-0,21)$ & $(-1,99)$ & $(-0,15)$ & $(-2,59)$ & $-0,86$ & $(-2,12)$ & $-0,72$ & $(-1,32)$ & $(-0,71)$ \\
\hline N & 132 & 22 & 23 & 10 & 10 & 21 & 41 & 217 & 10 & 46 & 8 \\
\hline
\end{tabular}

Źródło: Opracowanie własne. 
Tabela 5. Wpływ zmiany outlook na stopy zwrotu z akcji banków europejskich w podziale na poziom rozwoju gospodarczego

\begin{tabular}{|c|c|c|c|c|c|c|c|c|}
\hline \multirow{2}{*}{$\begin{array}{l}\text { Podziat } \\
\text { zmiana }\end{array}$} & \multicolumn{2}{|c|}{ High OECD } & \multicolumn{2}{|c|}{ High non OECD } & \multicolumn{2}{|c|}{ Upper } & \multicolumn{2}{|c|}{ Lower } \\
\hline & U & D & U & D & U & D & U & D \\
\hline \multicolumn{9}{|c|}{ pre-event window } \\
\hline \multirow[t]{2}{*}{ cons } & 0,00311 & 0,0103 & $-0,0098$ & $-0,0006$ & $0,0156^{\star * *}$ & $-0,0056$ & $0,0275^{\star}$ & $-0,0138^{*}$ \\
\hline & $-0,61$ & $-0,42$ & $(-0,50)$ & $(-0,03)$ & $(-3,28)$ & $(-1,10)$ & $-1,91$ & $(-2,56)$ \\
\hline$N$ & 199 & 229 & 40 & 48 & 189 & 202 & 47 & 63 \\
\hline \multicolumn{9}{|c|}{ event window } \\
\hline \multirow[t]{2}{*}{ cons } & $0,00587^{*}$ & 0,0009 & $-0,0017$ & $-0,021^{*}$ & 0,00114 & 0,00424 & 0,00262 & $-0,0072$ \\
\hline & $(-1,98)$ & $-0,21$ & $(-0,20)$ & $-1,89$ & $(-0,38)$ & $-1,11$ & $-0,69$ & $(-1,29)$ \\
\hline$N$ & 199 & 229 & 40 & 48 & 189 & 202 & 47 & 63 \\
\hline \multicolumn{9}{|c|}{ post-event window } \\
\hline \multirow[t]{2}{*}{ _cons } & $-0,0044$ & $-0,013^{*}$ & $-0,0145$ & $-0,011$ & 0,00346 & $-0,0087$ & $0.0317^{\star *}$ & $-0,0198^{* *}$ \\
\hline & $(-1,20)$ & $(-1,93)$ & $(-1,15)$ & $(-0,69)$ & $(-0,74)$ & $(-1,50)$ & $-2,95$ & $-2,66$ \\
\hline$N$ & 199 & 229 & 40 & 48 & 189 & 202 & 47 & 63 \\
\hline
\end{tabular}

Źródło: Opracowanie własne.

Następnie badaniu poddałam wpływ poziomu rozwoju gospodarczego na zmiany stóp zwrotu w wyniku korekty nastawienia. Okazuje się, iż zarówno poprawa, jak i pogorszenie generują ponadnormalne stopy zwrotu $\mathrm{z}$ cen akcji. W krajach wysoko rozwiniętych należących do OECD występuje silniejsza reakcja na pogorszenie nastawienia (w przypadku poprawy wzrost stóp o 0,58 pkt. proc., a pogorszenia - spadek o 1,3 pkt. proc.). Spadek stóp zwrotu o 2,1 pkt. proc. w momencie ogłoszenia negatywnego nastawienia obserwowany jest w przypadku banków z krajów wysoko rozwiniętych nienależących do OECD. Natomiast akcje banków z krajów o ponadprzeciętnym dochodzie reagują tylko na poprawę nastawienia w momencie przed ogłoszeniem informacji (wzrost stóp o 1,5 pkt. proc.). Akcje instytucji z krajów o dochodzie kształtującym się poniżej przeciętnego są szczególnie wrażliwe na poprawę nastawienia.

$\mathrm{W}$ przypadku każdej z agencji ratingowych zmiana watch list wywiera istotny statystycznie wpływ w czasie ogłoszenia informacji o korekcie. Poza Moody’s long term issuer watch list, w każdym $\mathrm{z}$ analizowanych przypadków należy zwrócić uwagę na oddziaływanie na stopy zwrotu tylko w sytuacji poprawy krótkoterminowego nastawienia. Mała liczba obserwacji może dawać nieco odmienne efekty, jednak po ręcznej analizie zjawiska wyniki wydają się poprawne. Należy zwrócić uwagę na fakt, że tylko największe agencje ratingowe nadają watch list bankom. Tak jak w przypadku długoterminowego nastawienia wraz ze spadkiem poziomu rozwoju gospodarczego kraju ponadnormalne stopy zwrotu rosną, co może być wynikiem oczekiwań inwestorów wyższych profitów z lokaty kapitału w krajach rozwijających się. 
Tabela 6. Wpływ zmiany watch list na stopy zwrotu $\mathrm{z}$ akcji banków europejskich $\mathrm{w}$ podziale na poszczególne credit ratings

\begin{tabular}{|c|c|c|c|c|c|c|c|}
\hline \multirow{2}{*}{$\begin{array}{c}\text { Agencja } \\
\text { miana }\end{array}$} & \multirow{2}{*}{$\begin{array}{c}\text { Moody's } \\
\text { Long-term } \\
\text { Issuer Rating }\end{array}$} & \multicolumn{2}{|c|}{$\begin{array}{l}\text { R\&I Long-term Issuer } \\
\text { Rating }\end{array}$} & \multirow{2}{*}{$\begin{array}{c}\text { S\&P Long- } \\
\text { term Issuer } \\
\text { Rating } \\
\text { U }\end{array}$} & \multicolumn{2}{|c|}{$\begin{array}{c}\text { Moody's Long-term Bank } \\
\text { Deposit }\end{array}$} & \multirow{2}{*}{$\begin{array}{c}\text { Moody's } \\
\text { Short-term } \\
\text { Bank Deposit } \\
\text { U }\end{array}$} \\
\hline & & U & D & & $U$ & D & \\
\hline \multicolumn{8}{|c|}{ pre-event window } \\
\hline \multirow[t]{2}{*}{ cons } & $-0,0461$ & 0,072 & 0,106 & 0,00896 & $-0,0257$ & $-0,0298$ & $-0,0225$ \\
\hline & $(-0,83)$ & $-0,35$ & $-0,51$ & $-0,23$ & $(-0,92)$ & $(-0,52)$ & $(-0,57)$ \\
\hline$N$ & 2 & 2 & 2 & 3 & 4 & 5 & 3 \\
\hline \multicolumn{8}{|c|}{ event window } \\
\hline \multirow[t]{2}{*}{ Cons } & $-0,0371^{\star \star \star}$ & 0,0958 ** & 0,113 & $-0,0344$ & $0,0293 * * \star$ & 0,00893 & $0,0322^{\star \star}$ \\
\hline & $-3,14$ & $(-2,06)$ & $-0,66$ & $(-0,95)$ & $(-3,32)$ & $-0,6$ & $(-2,75)$ \\
\hline$N$ & 2 & 2 & 2 & 3 & 4 & 5 & 3 \\
\hline \multicolumn{8}{|c|}{ post-event window } \\
\hline \multirow[t]{2}{*}{ Cons } & $-0,108$ & $-0,0992$ & $-0,0348$ & $-0,0697$ & $-0,0095$ & $-0,0337$ & $-0,0103$ \\
\hline & $(-1,50)$ & $(-1,11)$ & $(-0,27)$ & $(-0,70)$ & $(-0,24)$ & $(-0,99)$ & $(-0,19)$ \\
\hline$N$ & 2 & 2 & 2 & 3 & 4 & 5 & 3 \\
\hline
\end{tabular}

Źródło: Opracowanie własne.

Tabela 7. Wpływ zmiany watch list na stopy zwrotu $\mathrm{z}$ akcji banków europejskich $\mathrm{w}$ podziale na poziom rozwoju gospodarczego

\begin{tabular}{|c|c|c|c|c|}
\hline Podział & High OECD & High non OECD & \multicolumn{2}{|c|}{ Upper } \\
\hline u & U & D & U & D \\
\hline \multicolumn{5}{|c|}{ pre-event window } \\
\hline \multirow[t]{2}{*}{ _cons } & $-0,0684^{* * *}$ & $-0,0023$ & 0,00387 & $-0,015$ \\
\hline & $(-3,60)$ & $(-0,06)$ & $-0,1$ & $(-0,31)$ \\
\hline$N$ & 4 & 6 & 9 & 9 \\
\hline \multicolumn{5}{|c|}{ event window } \\
\hline \multirow[t]{2}{*}{ _cons } & $-0,0147^{\star * *}$ & $-0,0107$ & $-0,0589 * * *$ & 0,038 \\
\hline & $(-4,43)$ & $(-0,67)$ & $(-5,56)$ & $-1,11$ \\
\hline$N$ & 4 & 6 & 9 & 9 \\
\hline \multicolumn{5}{|c|}{ post-event window } \\
\hline \multirow[t]{2}{*}{ _cons } & 0,0466 & $-0,0052$ & $-0,0863^{\star \star}$ & $-0,0864^{*}$ \\
\hline & $-1,5$ & $(-0,33)$ & $(-4,72)$ & $(-2,08)$ \\
\hline$N$ & 4 & 6 & 9 & 9 \\
\hline
\end{tabular}

Źródło: Opracowanie własne. 


\section{Podsumowanie}

Celem artykułu była weryfikacja wpływu zmian oczekiwań credit ratings banków na stopy zwrotu z akcji banków przy uwzględnieniu poziomu rozwoju gospodarczego. Zweryfikowana została hipoteza badawcza na temat: ceny akcji banków reagują silniej na obniżkę oczekiwań credit ratings banków zarówno w przypadku krajów rozwiniętych, jak i rozwijających się. Przeprowadzone analizy dowiodły, iż $\mathrm{w}$ przypadku zmiany krótko- i długoterminowego nastawienia stopy zwrotu $\mathrm{z}$ akcji banków reagują silniej na negatywną zmianę. Ceny akcji są bardziej wrażliwe na informacje publikowane przez duże agencje ratingowe, lecz zauważalny jest wpływ R\&I czy JCR. W przypadku pogorszenia nastawienia zmiany proponowane przez większą liczbę agencji odgrywają istotną rolę. Ponadto wraz ze wzrostem poziomu rozwoju gospodarczego rynek akcji słabiej reaguje na zmiany outlooks. Może to być podyktowane chęcią generowania wyższych zysków oraz pewnością inwestorów co do lokowania środków w krajach rozwiniętych. Należy dodać, że tylko duże agencje ratingowe publikują informację na temat krótkoterminowego nastawienia wobec credit ratings banków. Krótkookresowa prognoza wywiera wpływ tylko na stopy zwrotu w momencie publikacji informacji. Otrzymane wyniki mogą sugerować, iż mniejsze agencje ratingowe nie są skłonne ponosić dodatkowych kosztów związanych z publikacją informacji w krótkim okresie. Zaistniała sytuacja może być wynikiem również słabszego zainteresowania rynku finansowego watch lists.

\section{Bibliografia}

Agarwal S., Chen V., Zhang W., The Information Value of Credit Rating Reports, „Management Science" 2016, Vol. 62, Issue 7.

Almeida H., Cunha I., Ferreira M.A., Restrepo F., The Real Effects of Credit Ratings: The Sovereign Ceiling Channel, „Journal of Finance” 2016, w druku.

Beckmann K.S., Jin C., The Impact of REIT Ratings on Stock Price and Shareholder Wealth, „International Real Estate Review” 2013, Vol. 16, No. 2, s. 134-146.

Bremer M., Pettway R.H., Information and the market's perceptions of Japanese bank risk: Regulation, environment, and disclosure, „Pacific-Basin Finance Journal” 2002, No. 10, s. 119-139.

Calderoni F., Colla P., Gatti S., Rating Changes: The European Evidence, „Carefin Research Paper Series" June 2009. 
Elayan F.A., Hsu W.H., Meyer T.O., The informational content of credit rating announcements for share prices in a small market, „Journal of Economics and Finance” 2003, Vol. 27, No. 3, s. 337-356.

Griffin P.A., Sanvicente A.Z., Common Stock Returns and Rating Changes: A Methodological Comparison, „Journal of Finance” 1982, No. 37, s. 103-120.

Gropp R., Richards A.J., Rating agency actions and the pricing of debt and equity of European banks: what can we infer about private sector monitoring of bank soundness?, „European Central Bank Working Paper" August 2001, No. 76.

Grothe M., Market pricing of credit rating signals, „EBC Working Paper Series” December 2013, No. 1623.

Hand J.R.M., Holthausen R.W., Leftwich R.W., The Effect of Bond Rating Agency Announcements on Bond and Stock Prices, „The Journal of Finance” 1992, Vol. 47, No. 2, s. 733-752.

Hiu L., Nuttawat V., Puspakaran K., Effects of credit rating announcements: the Swedish stock market, „International Journal of Finance” 2004, Vol. 16, No. 1, s. 28-72.

Holthausen R.W., Leftwich R.W., The Effect of Bond Rating Changes on common Stock Prices, „Journal of Financial Economics” 1986, No. 17, s. 57-89.

Jones E., Mulet-Marquis Q., The Stock Market Reaction to Changes to Credit Ratings of US-Listed Banks, „Centre for Finance and Investment Discussion Paper Series” September 2014, DP2013-AEF03, British Accounting and Finance Association (BAFA) Scottish Area Group Conference.

Klimavičienė A., Sovereign Credit Rating Announcements and Baltic Stock Markets, „Organizations and Markets in Emerging Economies" 2011, Vol. 2, No. 1(3), s. 51-62.

Li H., Visaltanachoti N., Kesayan P., The Effects of Credit Rating Announcements on Shares in the Swedish Stock Market, „International Journal of Finance” 2004, Vol. 16, Issue 1, s. $28-72$.

Linciano N., The reaction of stock prices to rating changes, „CONSOB Quaderni di Finanza” June 2004, No. 57.

Mateev M., The Effect of Sovereign Credit Rating Announcements on Emerging Bond and Stock Markets: New Evidences, „Oxford Journal: An International Journal of Business \& Economics" 2012, No. 7(1), s. 28-41.

Poon W.P.H., Chan K.C., An Empirical Examination of the Informational Content of Credit Ratings in China, „Journal of Business Research” 2007, Vol. 61, No. 7, s. 790-797.

Rao S.V.D.N., U S., Impact of Credit Ratings (Upgrade and Downgrade) on Stock Prices in India, Proceedings of $23^{\text {rd }}$ International Business Research Conference, 18-20 November 2013, Marriott Hotel, Melbourne, Australia, ISBN: 978-1-922069-36-81.

Richards A., Deddouche D., Bank rating changes and bank stock returns - puzzling evidence from the emerging markets, „IMF Working Papers” 1999, No. WP/99/151.

Schweitzer R., Szewczyk S., Varma R., Bond Rating Agencies and Their Role in Bank Market Discipline, „Journal of Financial Services Research” 1992, No. 6, s. 249-263. 
Vassalou M., Xing Y., Equity returns following changes in default risk: New insights into the informational content of credit ratings, „Working Paper Columbia University” 2003.

Steiner M., Heinke V.G., Event Study Concerning International Bond Price Effects on Credit Rating Actions, „International Journal of Finance and Economics” 2001, No. 6, s. 139-157.

\section{Expectation of banks' credit ratings announcement changes and stock prices taking into account the level economic development}

The aim of the paper is verification of the following hypothesis the share prices of banks have stronger reaction to bank credit rating announcements changes for a downgrade, both in developed and developing economies. The analysis(event study method) has been based on data from Thomson Reuters for the years 1980-2015 for 24 countries. Outlooks and watch lists proposed by all credit rating agencies have been used as an independent variable. Daily differences between the logarithmized rates of return of banks' shares have been used as dependent variable.

Keywords: credit rating, outlook, watch list, credit risk, event study

\section{Prévisions de changements aux cotes de crédit des banques versus cours des actions, en tenant compte du niveau du développement économique du pays}

L'article vise à vérifier l'influence des prévisions de changements aux cotes de crédit des banques sur le taux de rendement des actions des banques, en tenant compte du niveau du développement économique. Suite à une analyse de littérature, l'hypothèse de recherche suivante a été proposée: les prix des actions changent de façon plus prononcée avec la diminution des prévisions des cotes de crédit des banques, tout aussi bien dans les pays développés que ceux en développement. L'étude a été réalisée à l'aide de la méthode event study sur les données provenant de Thomson Reuters pour les années 1980-2015, pour 24 pays. Outlooks (perspectives) et watch lists (listes de surveillance), proposés par toutes les agences de notation, ont été utilisés comme variable indépendante. Variations quotidiennes entre les taux de rendement logarythmiques des actions des banques ont été prises comme variable dépendante.

Mots-clés: cote de crédit, prévisions, watch list, risque de crédit, event study 


\section{Ожидание изменений в кредитных рейтингах банков и цены на акции, учитывая уровень экономического развития страны}

Цель данной статьи состоит в том, чтобы проверить влияние изменений в ожиданиях кредитных рейтингов банков на доходность акций банка, учитывая уровень экономического развития. В статье был проведен обзор литературы и была выдвинута следующая гипотеза: Цены на акции банков реагируют более сильно на снижение ожидаемых кредитных рейтингов банков как в развитых, так и в развивающихся странах. Анализ был подготовлен по данным Thomson Reuters за 1980-2015 гг. для 24 стран при использовании метода event study. B качестве независимой переменной использовались outlook и watch list, предлагаемые всеми рейтинговыми агентствами. В качестве зависимой переменной принимались ежедневные различия в логарифмах ставок доходности акций банков.

Ключевые слова: кредитный рейтинг, outlook, watch list, кредитный риск, event study 